\title{
A Comparative Analysis of COVID-19 Outbreak, Heterogeneous Vaccine Dissemination and Effectiveness of Public Health Strategies in African Countries
}

\section{Pramita Chowdhury ${ }^{1}$, Arunima Bhattacharya ${ }^{2}$, Sohini Bose ${ }^{3}$ and Arup Kumar Mitra ${ }^{4 *}$}

${ }^{1}$ Department of Biochemistry, University of Calcutta, West Bengal, India

${ }^{2}$ Department of Biotechnology, St. Xavier's College (Autonomous), 30 Mother Teresa

Sarani, Kolkata, West Bengal, India

${ }^{3}$ Department of Biophysics and Molecular Biology, Rajabazar Science College,

University of Calcutta, West Bengal, India.

${ }^{4}$ Department of Microbiology, St. Xavier's College (Autonomous), 30 Mother Teresa

Sarani, Kolkata, West Bengal, India

*Corresponding Author: Arup Kumar Mitra, Department of Microbiology, St.

Xavier's College (Autonomous), 30 Mother Teresa Sarani, Kolkata, West Bengal,

India.
Received: December 10, 2021

Published: January 31, 2022

(C) All rights are reserved by Arup Kumar

Mitra., et al.

\begin{abstract}
The entire globe even with organized public health system is suffering from COVID-19 pandemic due to the Increasing rate of transmissibility and pathogenicity of SARS-CoV-2. In Africa, where the pandemic is expanding, there are major loopholes in financial resources, knowledge, health-care infrastructure, protective equipment, response capacity etc. Apart from this, Africa is torn by hunger, others disease outbreaks like Ebola, AIDS, TB which weaken this continent to fight against COVID-19. Here we summarized (a) the current scenario of COVID-19 outbreak in 11 African countries (b) the state of public health care infrastructure that might shape the devastating effect of pandemic crisis (c) the mode of heterogeneity in vaccine distribution policy in 11 African countries and the impact of vaccination to manage the pandemic (d) the improved strategies of the roll-model African country to deal with the rampant COVID-19. We highlighted that many high-income country like South Africa, Nigeria etc. were unable to deal with the outbreak due to lack of planning, useful policies, effective strategies, but in spite of being that a number of low-income African countries like Rwanda, Seychelles etc. have taken action swiftly by activating necessary policies, financial tools, effective strategies of vaccination to combat the disease. Variations in epidemiology, socio-economic factors in Africa shape the pandemic in a dynamic way and therefore, the findings of this review unpack broad lessons relating to Africa's capacity, success story, and strategy to contain the pandemic that should be considered as a part of remarkable framework in COVID-19 management.
\end{abstract}

Keywords: SARS-CoV-2; COVID-19 Vaccine; COVID-19; Africa; COVAX

\section{Introduction}

The coronavirus-2019 (COVID-19) is a serious acute respiratory disease caused by severe acute respiratory syndrome coronavirus 2 (SARS-CoV-2). Among hundreds of viruses that belong to coronavirus family, this SARS-CoV-2 zoonotic pathogen was first notified by Chinese public health officials in December 2019, which caused pneumonia-like symptoms in Wuhan city of China [1]. This SARS-CoV-2 is highly contagious and spread rapidly within three months from its appearance to at least 216 countries with $53,976,457$ confirmed cases, 1,311,942 deaths and 34,772,744 recoveries as of November 15, 2020 [2] and this COVID-19 was de- 
clared as a global pandemic by World Health Organization (WHO) on March 11, 2020 [3].

According to several study reports, the mode of transmission of SARS-CoV-2 is through respiratory droplets of an infected person when they sneeze or cough and common clinical signs and symptoms are fever, fatigue, dyspnoea, dry cough and myalgia. Sometime severity can cause kidney failure, acute respiratory syndrome, pneumonia and even death [4]. The viral storm has transmitted from Europe and the United States to Russia and Brazil [5] and as of $22^{\text {nd }}$ August, 2021, 12:20 a.m. CEST; world meter reported 211,884,754 confirmed cases with 4,433,532 deaths and $189,629,888$ recoveries in 222 countries [6]. Currently, most affected countries with highest number of COVID-19 cases are US, Brazil, India, Russia and United Kingdom. Number of cases continues to rise worldwide and overwhelm some of the world's best healthcare systems. Africa is the last and the most vulnerable continent to be hit by COVID-19 because the rate of viral transmission should be high at low temperature and drier conditions [7]. Apart from climate condition, several comorbidities combined with poverty, poor healthcare services and restricted access to health facilities have strong impact on the rate of infection in sub-Saharan Africa [8]. The first case of COVID-19 was announced in Egypt on $14^{\text {th }}$ of February, 2020, and first confirmed case in sub-Saharan Africa was reported in Nigeria on $27^{\text {th }}$ of February, 2020 which was suspected to come from Italy on $25^{\text {th }}$ of February, 2020 [9]. Within three months, SARSCoV-2 had spread throughout the Africa and according to the Africa CDC report published on $18^{\text {th }}$ April 2020, 52 African countries had 19,895 confirmed cases, including 1,017 deaths and 4,642 recoveries. Among 52 countries, Comoros and Lesotho were still virusfree but on $13^{\text {th }}$ May 2020, first COVID-19 case was also reported in Lesotho [10]. It was suspected that most of the confirmed cases in Africa imported from the United States and Europe rather than from China, the epicentre of COVID-19. Experts anticipated that it could be challenging for Africa to control COVID-19 pandemic not only due to climate condition and socio-economic status but also the presence of large immunocompromised population and lack of proper awareness regarding the disease. Although few vaccines are currently available to treat COVID-19, social distancing, quarantine, isolation, national lockdowns, and travel restrictions are the key steps to control and reduced the spread of COVID-19 and as a result of which, like other countries, African economies are also struggling to cope up the situation. There is huge disparity in at- titude, knowledge and practice among African countries and that is reflecting in their success story towards the virus. A report from Ethiopia showed that a larger percentage of the populations were familiar with clinical symptoms, risk factors and mode of transmission of COVID-19 [11], whereas, another study conducted in SubSaharan Africa reported that under this pandemic situation, health and safety measures recommended by the WHO were ignored and compromised by larger population [12]. Therefore, the outcome of this review will reveal the statement based on comparative analogy of COVID outbreak among different African countries and try to unresolved the mystery behind the success rate of best model countries in respect to that of others.

Although there are various enriched and updated publications addressing the current scenario and socio-economic implications of COVID-19 outbreak in Africa, however our review attempts to provide an altogether comparative analysis of pandemic spread, vaccine distribution and policy responses in different African countries. Few questions have been addressed in this review. (1) Is the trend of COVID-19 outbreak comparable in most of the African countries? (2) What is the vaccine distribution rate and what are the strategies taken up by the government regarding the equal access of vaccine to prevent gradual increase of confirmed COVID cases in African countries? (3) Do African health systems have the capability to manage the pandemic? (4) What are the secrets behind the COVID-19 Success stories from the African Continent? It is therefore anticipated that this study could share valuable viewpoints on these pertinent questions related to Africa's responses and that will uncover the best model country and their strategies which will become the benchmark reference for future studies.

\section{Study selection}

Among 55 African countries, we have selected only 11 countries (Nigeria, South Africa, Egypt, Morocco, Ethiopia, Libya, Tunisia, Democratic Republic of the Congo, Rwanda, Seychelles, Tanzania) based on heterogeneity in gross domestic product (GDP) per capita and the death rate due to COVID-19. We reviewed several publications on COVID-19 status in Africa from 1st February, 2020 to $31^{\text {st }}$ August, 2021. Previous and current reports were extracted from the World Health Organization African Region, Centers for Disease Control and Prevention (CDC), Africa Centers for Disease Control and Prevention and from additional authentic sources. 


\section{Epidemiological profile of COVID-19 pandemic in Africa}

The prevalence of COVID-19 pandemic is highly heterogeneous and is considered one of the biggest pandemic to humans. According to the latest report published by World health organization, Regional office for Africa-15 ${ }^{\text {th }}$ August, 2021, 17:00 GMT, 47 countries are being affected by COVID-19 and majority of cases are asymptomatic [13]. Based on currently available data, $43 \%$ and $30 \%$ of confirmed cases are from Southern and Northern Africa regions respectively. First confirmed case was reported from Egypt and then in Algeria on $25^{\text {th }}$ February, followed by Nigeria on $27^{\text {th }}$ of February [14]. Other African countries announced their first COVID cases in March [15]. According to worldmeter info-August 25, 2021, 18:41 GMT, 5 out of 58 countries include South Africa (confirmed cases = $2,722,202$, deaths $=80,469)$, Morocco $($ confirmed cases $=829,137$, deaths $=12,079$ ), Tunisia (confirmed cases $=647,483$, deaths $=$ 22,860 ), Libya (confirmed cases $=300,455$, death $=4,126$ ), and Ethiopia (confirmed cases $=297,997$, deaths $=4,580$ ) are the most affected countries so far in Africa. This is mysterious that countries with higher values of GDP show high rate of incapability in COVID-19 control (Figure $1 \mathrm{~A}, \mathrm{~B}$ ). More than half of the total confirmed cases in Africa are covered by these 5 countries and more than two-thirds of all reported deaths in Africa are accounted by South Africa, Egypt and Tunisia [16]. Two out of 11 countries selected in your study show huge heterogeneity in COVID spread. Maximum numbers of confirmed cases are reported from South Africa whereas; Tanzania till now shows lower number of COVID cases. A heterogeneous spread of COVID-19 from February, 2020 to August, 2021 was observed for 11 African countries (Figure 1C).

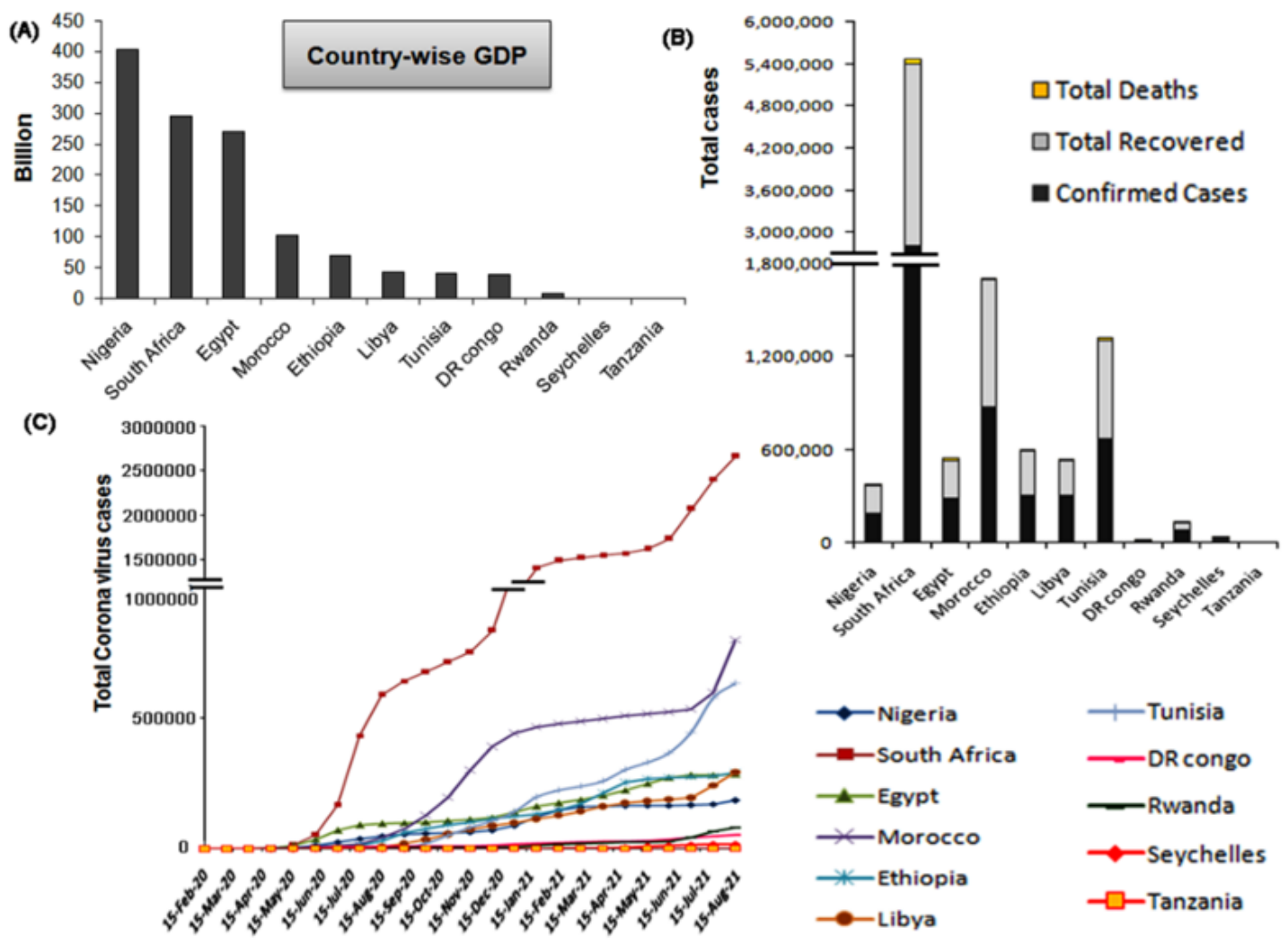

Figure 1: Comparison of Gross domestic product (GDP), Total confirmed COVID cases, deaths and recoveries and Month-wise trend of COVID-19 cases in 11 African countries (A) The bar graph represents GDP by countries (B) The plot indicates total number of COVID cases along with the number of deaths and recovered (C) The line graph portrays month-wise total coronavirus cases. 
Nigeria

SARS-CoV-2 virus came from Italy in Nigeria on $27^{\text {th }}$ February, 2020 [17]. Immediately, the Federal government of Nigeria restricted the entry in the five international airports on $28^{\text {th }}$ January 2020 to prevent the spread of coronavirus [18]. In addition, Nigeria Centre for Disease Control also announced to set up a Coronavirus Preparedness Group to diminish the effect of the virus [19]. Nigeria government announced total lockdown and banned all public gathering from March, 2020 and as of $27^{\text {th }}$ August 2021, 2,727,834 tests were done by Nigeria government. It is very unfortunate to know that many Nigerians still believe the virus is a scam and the number of cases recorded in the first wave of the pandemic was exaggerated to get more funds for states to enrich own official department [20]. Many of them overrule the health requirements and WHO's guideline and as a result of which till now 618 new cases were recorded from Nigeria as per the report published on $27^{\text {th }}$ August, 2021 [21].

\section{South Africa}

In South Africa, first known COVID-19 case was noticed in a male patient who was returning from Italy on $5^{\text {th }}$ March, 2020 [22] and on $23^{\text {rd }}$ march, they announced national lockdown. Unfortunately, after May, 2020, the national restriction was lowered to alert level 1 from alert level 4 as per the order given by the President of South Africa [23] and as a result of this mistake, South Africa again experienced a second wave of SARS-CoV-2 infections on December, 2020 [24]. During the time of February to March 2021, South Africa decided to unrestricted their lockdown structure and start vaccination program and as a consequence, delta variant as well as third wave of COVID-19 pandemic was hit the population on $31^{\text {st }}$ May, 2021 [25]. Delta variant is becoming the dominant strain and as of $21^{\text {st }}$ August, 2021, the death rate has exceeded gradually in South Africa due to insufficient beds, oxygen and overwhelming health service. Apart from their drawbacks, South Africa started testing people for SARS-CoV- 2 more efficiently from $28^{\text {th }}$ January, 2020 by the help of National Institute for Communicable Diseases (NICD), state hospitals, National Health Laboratory Service (NHLS), many private clinical pathology laboratories and private sector [26,27]. By $28^{\text {th }}$ June 2020,1567084 tests had been performed and then the private sector had overtaken the public sector to increase the test number. By $27^{\text {th }}$ August 2021, the total number of tests was $16,292,228$. In addition to many good aspects, 12,045 new COV-
ID-19 cases were still shown on $27^{\text {th }}$ August, 2021 in South Africa due to several loopholes [21].

\section{Egypt}

The first case in the Egypt was confirmed on $14^{\text {th }}$ February, 2020. The strain came from China [29]. Total number of 3,068,679 samples was diagnosed for SARS-CoV-2 virus and based on the report published on $27^{\text {th }}$ August 2021, 234 new cases were reported from this country [21].

\section{Morocco}

The first COVID-19 case in the Morocco was detected on $22^{\text {nd }}$ March, 2020 in a person returning from Italy [29]. Total number of $8,845,243$ samples was diagnosed for SARS-CoV-2 virus and as of $27^{\text {th }}$ August 2021, 6863 new cases were reported from this country [21].

\section{Ethiopia}

The first COVID-19 case in the Ethiopia was confirmed on $13^{\text {th }}$ march, 2020 in a Japanese citizen [30]. Initially, Ethiopian government shown causality but after that they announced lockdown and Ethiopian airlines suspended all flights from 30 affected countries. Total 3,210,062 peoples had been tested till date and as of $27^{\text {th }} \mathrm{Au}$ gust 2021, 1458 new cases were reported from the Ethiopia [21].

Libya

Libya is extremely vulnerable to the pandemic due to the Second Libyan Civil War [31]. Before the pandemic outbreak in Libya, the UN-recognised Government of National Accord announced total lockdown, closed the country's borders, suspended flights and banned foreign nationals from entering the country as their healthcare system was already on the verge of collapse. The first confirmed case was recorded on $24^{\text {th }}$ March, 2020 in a person returning from Saudi Arabia [32]. Total number of 1,503,172 samples was tested and based on the report published on $27^{\text {th }}$ August 2021, 1613 new cases were reported from this country [21].

\section{Tunisia}

The first case in the Tunisia was confirmed on $2^{\text {nd }}$ March, 2020. The transmission rate is significantly higher in this country but Tunisia recorded zero cases on $10^{\text {th }}$ May, 2020 [33]. Unfortunately, after May month, number of confirmed cases again started to rise and as of $27^{\text {th }}$ August 2021, 3763 new cases were reported from 
this country. Total number of 2,536,711 samples was diagnosed for SARS-CoV-2 virus [21].

\section{Democratic Republic of the Congo}

The first COVID-19 case in the Democratic Republic of the Congo (DRC) was confirmed on $10^{\text {th }}$ march, 2020. The Democratic Republic of the Congo is one of the poorest countries in the world, and their health care system is limited. Under this circumstance, COVID-19 crisis began along with Ebola epidemic [34]. President of the DRC ordered to close all borders, Schools, restaurants, places of worship, bars and flights [35]. Total 188,207 peoples had been tested till date and on $27^{\text {th }}$ July 2021, the delta variant had been identified in $76 \%$ of samples [36]. As of $26^{\text {th }}$ August 2021, 40 new cases were reported from the DRC [21].

\section{Rwanda}

The first case in the Rwanda was confirmed on $14^{\text {th }}$ March, 2020 [37]. This country has organized health care system, rapid testing procedure and trustable medical authority. Total number of 2,377,122 samples had been tested and 522 new cases were recorded on 27 $7^{\text {th }}$ August, 2021 [21]. Government of Rwanda has taken rapid action to control the spread of coronavirus. In addition to the lockdown, Rwanda National Police started to use the drones to deliver precaution messages to the Rwanda communities [38]. Despite all the limitations and lack of resources, Rwanda was able to control the pandemic situation effectively and as a result, they have received international praise for efficiency.

\section{Seychelles}

First two confirmed COVID cases were reported from Seychelles on $14^{\text {th }}$ March, 2020 in patients coming from Italy [39]. Seychelles announced full lockdown and imposed all possible restriction. It will be the first country in the Eastern Africa Region to reopen its museum during the pandemic. All international travelling was banned by government and they announced that all arriving passengers need to present a recent negative PCR test, and test negative again on their sixth day in Seychelles [40]. Total number of 21,504 samples was diagnosed for SARS-CoV-2 virus and as of $26^{\text {th }}$ August 2021, 183 new cases with no death were reported from this country [21].

\section{Tanzania}

The first COVID-19 case in the Tanzania was confirmed on $16^{\text {th }}$ march, 2020 [41]. Suddenly, Tanzania authority stopped reporting case numbers in May, 2020 and, President of Tanzania declared this country as a COVID-free country on $8^{\text {th }}$ June, 2020. This country shut down all COVID-19 test centre and patients with any COVID-related symptoms have been denied for testing. In the first week of 2021, when 3 persons returning from Tanzania tested positive [42], Tanzania government was requested by WHO to start reporting COVID-19 cases, share data, follow all health restrictions and prepare the platform for vaccination [43]. From the time of $21^{\text {st }}$ February 2021, President of this country had started to request Tanzanians to take precautions against the spread of SARS-CoV-2. They don't even disclose the data regarding COVID-testing. As of $10^{\text {th }}$ August 2021, 350 new cases were reported from Tanzania [21].

Although the fundamental cause for the heterogeneity of COVID-19 cases among different African countries remains unknown, experts highlight few facts including the timing of the SARS-CoV-2 virus outbreak, dissimilar preparedness and response, experience from the previous pandemics, diverse health care systems for testing and treatment, demographic and environmental factors, host genetics and social factors. Apart from these, another key factor related to the heterogeneity of COVID-19 outbreak is the rate of immunization of African population by vaccination agenda.

COVID-19 vaccine dissemination, access, policies and challenges in Africa

The World Health Organization (WHO) in Africa and Africa Center Disease Control (Africa CDC) have begun vaccination programs in many African countries to ensure equal access to the COVID-19 vaccines as several African regions are still suffering from the viral load and lack of effective strategies regarding vaccine distribution. As of $5^{\text {th }}$ July 2021, vaccination movements had began in 51 African countries with 36.5 million people getting at least one dose [44]. Africa CDC has requested the international community to come together and help poor African countries with COVID-19 vaccines as many of them cannot afford the vaccine due to its costs and other negative factors. Over 10 vaccines are currently circulating among selected 11 African countries. Notable characteristics of popular vaccines, percentage of population immunized by doses of vaccine, vaccination phase of all circulated vaccines in 11 African countries are tabulated in table 1.

Trust in the vaccines is very important, and is vitally dependant on the capability of governments to circulate the benefits, safety 


\begin{tabular}{|c|c|c|c|c|c|c|c|c|}
\hline $\begin{array}{l}\text { Country } \\
\text { Name }\end{array}$ & Vaccine & $\begin{array}{l}\text { Vaccine } \\
\text { Biology }\end{array}$ & Manufacturer & $\begin{array}{c}\text { Vaccination } \\
\text { initiation } \\
\text { date }\end{array}$ & $\begin{array}{c}\% \text { of } \\
\text { population } \\
\text { given first } \\
\text { dose }\end{array}$ & $\begin{array}{c}\text { \% of } \\
\text { population } \\
\text { given } \\
\text { second } \\
\text { dose }\end{array}$ & $\begin{array}{c}\text { Total doses } \\
\text { administrated } \\
\text { up to } 28 / 08 / 21\end{array}$ & $\begin{array}{l}\text { Vacci- } \\
\text { nation } \\
\text { phase }\end{array}$ \\
\hline \multirow[t]{2}{*}{ South Africa } & $\begin{array}{c}\text { Johnson and } \\
\text { Johnson }\end{array}$ & Viral vector & $\begin{array}{l}\text { JanssenPhar- } \\
\text { maceuticals }\end{array}$ & \multirow[t]{2}{*}{$17 / 02 / 21$} & \multirow[t]{2}{*}{$5.7 \%$} & \multirow[t]{2}{*}{$9.3 \%$} & \multirow[t]{2}{*}{$11,924,972$} & \multirow[t]{2}{*}{3} \\
\hline & $\begin{array}{l}\text { Pfizer-BioN- } \\
\text { Tech }\end{array}$ & mRNA & BioNTech & & & & & \\
\hline \multirow[t]{4}{*}{ Nigeria } & $\begin{array}{l}\text { Oxford-Astra- } \\
\text { Zeneca }\end{array}$ & Viral vector & $\begin{array}{l}\text { Oxford Uni- } \\
\text { versity and } \\
\text { AstraZeneca } \\
\end{array}$ & \multirow[t]{4}{*}{$05 / 03 / 21$} & \multirow[t]{4}{*}{$0.54 \%$} & \multirow[t]{4}{*}{$0.67 \%$} & \multirow[t]{4}{*}{$3,967,013$} & \multirow[t]{4}{*}{1} \\
\hline & Sputnik V & Viral vector & $\begin{array}{c}\text { Gamaleya } \\
\text { Research } \\
\text { Institute of } \\
\text { Epidemiology } \\
\text { and } \\
\text { Microbiology }\end{array}$ & & & & & \\
\hline & Moderna & modRNA & $\begin{array}{c}\text { Moderna, } \\
\text { NIAID and } \\
\text { BARDA } \\
\end{array}$ & & & & & \\
\hline & $\begin{array}{l}\text { Pfizer-BioN- } \\
\text { Tech }\end{array}$ & mRNA & BioNTech & & & & & \\
\hline DRC & $\begin{array}{l}\text { Oxford-Astra- } \\
\text { Zeneca }\end{array}$ & Viral vector & $\begin{array}{c}\text { Oxford } \\
\text { University and } \\
\text { AstraZeneca }\end{array}$ & $19 / 04 / 21$ & $0.082 \%$ & $0.01 \%$ & 87,910 & 1 \\
\hline \multirow[t]{2}{*}{ Tunisia } & Sputnik V & Viral vector & $\begin{array}{c}\text { Gamaleya } \\
\text { Research } \\
\text { Institute of } \\
\text { Epidemiology } \\
\text { and } \\
\text { Microbiology }\end{array}$ & \multirow[t]{2}{*}{$13 / 03 / 21$} & \multirow[t]{2}{*}{$16 \%$} & \multirow[t]{2}{*}{$15 \%$} & \multirow[t]{2}{*}{$5,134,991$} & \multirow[t]{2}{*}{1} \\
\hline & $\begin{array}{l}\text { Pfizer-BioN- } \\
\text { Tech }\end{array}$ & mRNA & BioNTech & & & & & \\
\hline \multirow[t]{2}{*}{ Ethiopia } & $\begin{array}{l}\text { Oxford-Astra- } \\
\text { Zeneca }\end{array}$ & Viral vector & $\begin{array}{c}\text { Oxford } \\
\text { University and } \\
\text { AstraZeneca }\end{array}$ & \multirow[t]{2}{*}{$13 / 03 / 21$} & \multirow[t]{2}{*}{-} & \multirow[t]{2}{*}{-} & \multirow[t]{2}{*}{$2,394,866$} & \multirow[t]{2}{*}{1} \\
\hline & Sinopharm & $\begin{array}{l}\text { Inactivated } \\
\text { Virus }\end{array}$ & $\begin{array}{c}\text { Sinopharm's } \\
\text { Beijing } \\
\text { Institute of } \\
\text { Biological } \\
\text { Products }\end{array}$ & & & & & \\
\hline
\end{tabular}


A Comparative Analysis of COVID-19 Outbreak, Heterogeneous Vaccine Dissemination and Effectiveness of Public Health Strategies in African Countries

\begin{tabular}{|c|c|c|c|c|c|c|c|c|}
\hline \multirow[t]{4}{*}{ Egypt } & Sinopharm & $\begin{array}{c}\text { Inactivated } \\
\text { Virus }\end{array}$ & $\begin{array}{l}\text { Sinopharm's } \\
\text { Beijing } \\
\text { Institute of } \\
\text { Biological } \\
\text { Products }\end{array}$ & \multirow[t]{4}{*}{$24 / 01 / 21$} & \multirow[t]{4}{*}{$2.1 \%$} & \multirow[t]{4}{*}{$2.8 \%$} & \multirow[t]{4}{*}{$8,004,586$} & \multirow[t]{4}{*}{1} \\
\hline & $\begin{array}{c}\text { Oxford-Astra- } \\
\text { Zeneca }\end{array}$ & Viral vector & $\begin{array}{c}\text { Oxford } \\
\text { University and } \\
\text { AstraZeneca }\end{array}$ & & & & & \\
\hline & Sinovac & $\begin{array}{c}\text { Inactivated } \\
\text { Virus }\end{array}$ & $\begin{array}{l}\text { Sinovac } \\
\text { Biotech }\end{array}$ & & & & & \\
\hline & Sputnik V & Viral vector & $\begin{array}{c}\text { Gamaleya } \\
\text { Research } \\
\text { Institute of } \\
\text { Epidemiology } \\
\text { and } \\
\text { Microbiology }\end{array}$ & & & & & \\
\hline \multirow[t]{3}{*}{ Morocco } & $\begin{array}{c}\text { Oxford-Astra- } \\
\text { Zeneca }\end{array}$ & Viral vector & $\begin{array}{c}\text { Oxford } \\
\text { University and } \\
\text { AstraZeneca }\end{array}$ & \multirow[t]{3}{*}{$28 / 01 / 21$} & \multirow[t]{3}{*}{$10 \%$} & \multirow[t]{3}{*}{$38 \%$} & \multirow[t]{3}{*}{$32,541,843$} & \multirow[t]{3}{*}{1} \\
\hline & Sinopharm & $\begin{array}{l}\text { Inactivated } \\
\text { Virus }\end{array}$ & $\begin{array}{l}\text { Sinopharm's } \\
\text { Beijing } \\
\text { Institute of } \\
\text { Biological } \\
\text { Products }\end{array}$ & & & & & \\
\hline & $\begin{array}{c}\text { Pfizer-BioN- } \\
\text { Tech }\end{array}$ & mRNA & BioNTech & & & & & \\
\hline \multirow[t]{2}{*}{ Tanzania } & CoronaVac & $\begin{array}{c}\text { Inactivated } \\
\text { Virus }\end{array}$ & $\begin{array}{l}\text { Sinovac } \\
\text { Biotech }\end{array}$ & \multirow[t]{2}{*}{$06 / 07 / 21$} & \multirow[t]{2}{*}{$0.36 \%$} & \multirow[t]{2}{*}{-} & \multirow[t]{2}{*}{218,621} & \multirow[t]{2}{*}{ - } \\
\hline & $\begin{array}{c}\text { Janssen } \\
\text { COVID-19 } \\
\text { vaccine }\end{array}$ & Viral vector & $\begin{array}{c}\text { Janssen } \\
\text { Pharmaceuti- } \\
\text { cals }\end{array}$ & & & & & \\
\hline \multirow[t]{3}{*}{ Libya } & $\begin{array}{c}\text { Oxford-Astra- } \\
\text { Zeneca }\end{array}$ & Viral vector & $\begin{array}{c}\text { Oxford } \\
\text { University and } \\
\text { AstraZeneca }\end{array}$ & \multirow[t]{3}{*}{$11 / 04 / 21$} & \multirow[t]{3}{*}{$11 \%$} & \multirow[t]{3}{*}{$0.75 \%$} & \multirow[t]{3}{*}{$1,022,882$} & \multirow[t]{3}{*}{ - } \\
\hline & Sputnik V & Viral vector & $\begin{array}{c}\text { Gamaleya } \\
\text { Research } \\
\text { Institute of } \\
\text { Epidemiology } \\
\text { and } \\
\text { Microbiology }\end{array}$ & & & & & \\
\hline & CoronaVac & $\begin{array}{c}\text { Inactivated } \\
\text { Virus }\end{array}$ & $\begin{array}{l}\text { Sinovac } \\
\text { Biotech }\end{array}$ & & & & & \\
\hline \multirow[t]{2}{*}{ Seychelles } & BBIBP-CorV & $\begin{array}{c}\text { Inactivated } \\
\text { Virus }\end{array}$ & $\begin{array}{l}\text { Sinopharm's } \\
\text { Beijing } \\
\text { Institute of } \\
\text { Biological } \\
\text { Products }\end{array}$ & \multirow[t]{2}{*}{$10 / 01 / 21$} & \multirow[t]{2}{*}{$4.1 \%$} & \multirow[t]{2}{*}{$70 \%$} & \multirow[t]{2}{*}{143,490} & \multirow[t]{2}{*}{-} \\
\hline & $\begin{array}{c}\text { Oxford-Astra- } \\
\text { Zeneca }\end{array}$ & Viral vector & $\begin{array}{c}\text { Oxford } \\
\text { University and } \\
\text { AstraZeneca }\end{array}$ & & & & & \\
\hline
\end{tabular}


A Comparative Analysis of COVID-19 Outbreak, Heterogeneous Vaccine Dissemination and Effectiveness of Public Health Strategies in African Countries

\begin{tabular}{|l|c|c|c|c|c|c|c|}
\hline Rwanda & $\begin{array}{c}\text { Oxford-Astra- } \\
\text { Zeneca }\end{array}$ & Viral vector & $\begin{array}{c}\text { Oxford } \\
\text { University and } \\
\text { AstraZeneca }\end{array}$ & $05 / 03 / 21$ & $5.7 \%$ & $3.6 \%$ & $1,723,562$ \\
\cline { 2 - 7 } & $\begin{array}{c}\text { Pfizer-BioN- } \\
\text { Tech }\end{array}$ & mRNA & BioNTech & & - & \\
\hline
\end{tabular}

Table 1: Comparison of individual vaccine biology, percentage of population immunized by $1^{\text {st }}$ and $2^{\text {nd }}$ doses of vaccine, vaccination phases of all circulated vaccines in 11 African countries. (Source: https://graphics.reuters.com/world-coronavirus-tracker-and-maps/ vaccination-rollout-and-access/, https://ourworldindata.org/covid-vaccinations?country=).

and effectiveness of vaccination. To achieve the herd immunity, $60-70 \%$ of the population needs to be vaccinated. The percentage of vaccination coverage is highly heterogeneous in Africa, ranging from $0 \%$ (in six countries) to $66 \%$ (in the Seychelles) [45]. Africa CDC introduces advanced policies, increases coordination with International domain and they are trying to mobilize resources to increase vaccine supply and the coverage of vaccine distribution. The COVAX Facility is co-led by Gavi, CEPI, WHO and UNICEF whose aim is to accelerate the development and manufacture capacity of COVID-19 vaccines. Most of the African countries has so far invested a large amount and got their vaccines from the Serum Institute of India under the COVAX scheme. Unfortunately, Africa was facing shortage of vaccine as India halted vaccine exports in response to its own urgent needs.

In Nigeria, the AstraZeneca/Oxford and Johnson and Johnson vaccines have started to roll out in 36 states of the country in less than two months after arrival from the Serum Institute of India (SII), from Mumbai to Abuja through COVAX facility [46]. National Primary Health Care Development Agency (NPHCDA) has initiated vaccination among frontline healthcare workers and people at higher risk in Nigeria. This country is the first one receiving the doses from COVAX due to their excellent level of preparedness (national vaccination plans, cold chain infrastructure, stockpiling of half a billion syringes, masks, gloves, safety boxes etc.). Infection and death rate continue to rise in Nigeria as conspiracy theories, misinformation about COVID vaccination and religious believe have spread in Nigeria strongly, especially in the rural area. Although initially South Africa had been slow to administer AstraZeneca COVID-19 vaccines due to concerns about its efficacy against emerging variants, after receiving the Johnson and Johnson vaccine they started to conduct the vaccination program effectively. Johnson and Johnson and Pfizer-BioNTech vaccine appeared to be $57 \%$ and $100 \%$ effective in South Africa respectively. Government of South Africa set a target to build up herd immunity in $67 \%$ of population by rolling out of vaccine. Frontline health workers were targeted first for vaccination and more than 40 million people will be immunized in near future by the provincial departments, district health teams and the private health sector. Three platforms are established by South Africa. The first is a work-based vaccine programme for public and private hospital staff. Second is an outreach based vaccination programme and thirdly, they would like to establish vaccination centres in remote areas. Based on the South African Bill of Rights (section 36), they are going to introduce a mandatory vaccination policy to save life, reduce public risk as the majority of deaths in South Africa are occurring among the unvaccinated. On other hand, DRC is suffering from lower rate of vaccination due to poor healthcare infrastructure, political instability and spread of misinformation. Currently, Tunisia suffered from high infection rate and political instability but they had administrated all the doses of COVID-19 vaccine so far received by them. On August 2021, Tunisia launched vaccination drive for over 40 ages. However they don't have optimal management system, they are trying to achieve their vaccination goal soon. Ethiopian government and National Deployment and Vaccination Plan (NDVP) organized few campaign where they highlighted the use of face mask, hand hygiene and others precautions along with vaccination and they aim to vaccinate $20 \%$ of their population by the end of 2021 with the help of COVAX facility. On the other hand, the Ministry of Health and Population of Egypt guides on rising vaccination rates and more than 400 vaccination centers opened where vaccination is accessible not only to Egyptians, but to all people in Egypt, including refugees and migrants. In Morocco, 12 to 17-year-olds children are now eligible to receive COVID-19 vaccine doses. They open smart vaccination center using digitalization platform where citizens can track their vaccination process, from registration to receipt of their second dose, by scanning a QR code using their phone. This digi- 
tal process helps the Morocco to administer most vaccine doses of any country in Africa. Vaccination process was lodged in Tanzania up to February, 2021. They had no plan to accept COVID-19 vaccine. Health minister and the ex-President of this country warned journalists about reporting unofficial figures on COVID-19 disease and they stopped releasing official COVID-19 statistics. They circulated that vaccination are dangerous for population and declared the country as a COVID-19 free country because of God's intervention. This is very unfortunate that they are hiding their all data and increasing the life risk of Tanzanians [47]. However new President of Tanzania urged all Tanzanians to get vaccinated and requested to release the correct data of COVID-19. COVID-19 vaccines effectively started to rollout in Libya by the help of Japan whereas, Seychelles did not collaborate with the COVAX facility programme due to its high cost of embarking but, they received the support from few international partners. The Health Minister of this country decided to vaccinate 18 to 60 years of age's people with the SINOPHARM vaccine and people above the age of 60 years will be vaccinated by COVISHIELD (Oxford AstraZeneca) vaccine. Seychelles established the National Technical Working Group (NTWG) and 7 thematic groups were established for effective vaccination. They have a wellfunctioning monitoring system for adverse events following routine immunization (AEFI) and vaccine safety issues. Although Seychelles is the most vaccinated country in the world, currently more COVID-19 cases are relapsing in the country which might be due to the lower affectivity of Sinopharm vaccine [48]. Besides, Rwanda, a poor country by all measures, started third phase of COVID-19 vaccination using the Pfizer vaccine where they are targeting adults 18 year. Rwanda arranged mobile teams those were moving door to door to vaccinate older people. The rate of hospital admissions and new cases has been reduced slightly due to their scientific strategy and noticeable efficiency in controlling pandemic situation.

Learning from the best: Predicting Africa's model country responding best to the COVID crisis

Depending on efficient policy of COVID-19 vaccination or effort to stop the pandemic, the most secured countries of Africa under COVID-19 outbreak were highlighted in this study. High vaccination rates or high income are not proportionally associated with better disease management. Success story of any country should depend not only on its population, but also on other factors such as health infrastructure, preparedness, rate of disease transmission, strict regulation under government policy, stringency index etc. Ac- cording to the "Covid Performance" index published by the Lowy Institute, the Australian think-tank, Rwanda's efforts to tackle pandemic crisis was recognized internationally and they have received international praise for efficiency but, as per GDP data, Rwanda is a poor country in Africa. In spite of being a low income country, they have organized health care system, rapid testing procedure and trustable medical authority. Rwanda increased its testing capacity immediately and over 4,000 tests were performed on daily basis and up to $1,012,451$ tests were done by $1^{\text {st }}$ March, 2021. The remarkable effort has directed the country to being ranked first in Africa and sixth globally in managing the pandemic crisis [49]. Rwanda uses bracelet on COVID-positive patient's hand to track their movement so that they are unable to move elsewhere and infect healthy persons. The Robotic treatment of this country is an incredible example for richer country. The five human-size robots installed in July 2020 to reduce the risks for health-workers and by February, 2021 they deployed three more UV-robots to disinfect hospitals and public places. The death per capita in Rwanda is the lowest in respect to that of others low, middle or high-income countries with well established health system.

After Rwanda, another country responding well to tackle the COVID situation is Seychelles. This country has become known as the world's most vaccinated country for COVID-19. As per the report published on $26^{\text {th }}$ August 2021, there was no report of deaths among fully vaccinated people due to COVID-19. Although Seychelles has well-functioning monitoring system, this most-vaccinated nation has experienced a spike in new COVID cases. The reason might be the dominance of new variants or in effectivity of administrated vaccine due to mass failures of the cold-chain logistics needed for transport and storage of vaccine.

On the other hand, Tunisia's good result regarding vaccination surprised everyone even though they don't have optimal health care system. This country imposes enforced quarantine on all visitors who have not been fully vaccinated. Currently, Tunisia suffered from high fatality rate due to oxygen shortage and sudden disorganization in vaccination policy.

A very unfortunate situation was observed for Tanzania. The underlying cause behind the low number of COVID cases in Tanzania is their hiding tendency. WHO still has no authentic data from Tanzania on its fatality rate and COVID response. Experts suspected that there might be a chance of hidden epidemic too. 
In spite of being a high income country, South Africa is suffering the most from COVID-19 crisis. The reasons include larger population, causality of high percentage of younger population, lack of strategy and missteps regarding vaccination apart from its dependency on the fragile COVAX arrangement, sudden unplanned halting of vaccine roll-out system, refuse the use of NOVAVAX, limited vaccination centre. Morocco achieved highest vaccination rates in the first phase [50] but after that they started to relax restrictions for fully vaccinated citizens and resume international flights and as a result of which COVID cases have become increased gradually. Countries that rank below average more or less for the above mentioned reasons are Ethiopia, Nigeria, Morocco, Libya and lastly, South Africa (Figure 2 A, B).

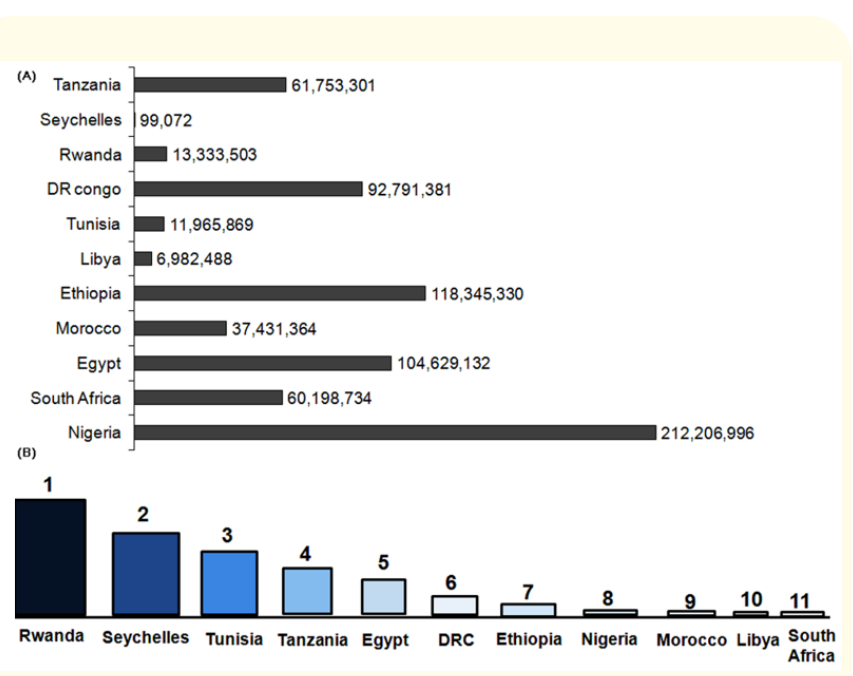

Figure 2: Population distribution and ranking of 11 African countries based on their success in pandemic crisis (A) The graph indicates the population distribution in 11 African countries (B) Countries with their rank based on their response to COVID-19.

\section{Conclusion}

The COVID-19 pandemic has taught us key lessons about drastic change of situation, crisis, importance of health, communication, misinformation, preparedness. Worldwide scenario from February 2020 indicated that case fatality rate (the ratio between number of deaths and number of confirmed cases) is fickle. The country that is the best today may be the worst tomorrow. South Africa is suffering most whereas, Rwanda is responding best to cope up the pandemic crisis. As for example, taking the lesson from 2020-2021,
South Africa has began to rectify their strategies. They are planning to purchase the updated vaccines which could be effective against the variants of concern. WHO Africa's coordinator for immunization and vaccines development stated that African nations had damaged arround 450,000 vaccine doses due to lack of storage and distribution planning whereas, many African's countries shown effective strategy and noticeable preparedness regarding vaccination and disease control. Therefore, our review provides a firm knowledge about the successful policy, missteps and ambiguities in the disease management based on comparative analysis in 11 different African countries. This will provide useful clues for reorganizing decision, interpretation of successful strategic plan and overcoming obstacles in the near desired future.

\section{Summary}

The entire globe is suffering from COVID-19 pandemic. In Africa, where the pandemic is expanding, there are major loopholes in resources, health-care infrastructure, and response capacity. Here we summarized (a) the COVID-19 outbreak and the state of public health infrastructure in 11 African countries (b) the mode of heterogeneity in vaccine distribution and (c) the improved strategies of the roll-model African country to deal with the rampant COVID-19. We highlighted that many high-income countries like South Africa, Nigeria were unable to deal with the outbreak due to lack of planning, whereas Rwanda, Seychelles like low-income countries have taken action swiftly by activating necessary strategies. The findings of this review unpack broad lessons relating to Africa's capacity to combat the pandemic.

\section{Acknowledgment}

PC is supported by CSIR-Direct SRF fellowships from CSIR. Special thanks to St. Xavier's College, Kolkata for giving me the opportunity for being a part of COVID study.

\section{Disclosure Statement}

The authors declare no competing interests.

\section{Bibliography}

1. Zhou P., et al. "A pneumonia outbreak associated with a new coronavirus of probable bat origin". Nature 579.7798 (2020): 270-273.

2. World Health Organization. "WHO coronavirus disease (COVID-19) dashboard". World Health Organization, Geneva, Switzerland (2020). 
3. Abdelhafiz AS., et al. "Knowledge, Perceptions, and Attitude of Egyptians Towards the Novel Coronavirus Disease (COVID-19)". Journal of Community Health 45.5 (2020): 881-890.

4. Dhand R and Li J. "Coughs and Sneezes: Their Role in Transmission of Respiratory Viral Infections, Including SARS-CoV-2". American Journal of Respiratory and Critical Care Medicine 202.5 (2020): 651-659.

5. Wetsman N. "WHO declares the outbreak of the new coronavirus is a pandemic". The Verge (2020).

6. https://www.worldometers.info/coronavirus/

7. El-Sadr WM and Justman J. "Africa in the Path of COVID-19". New England Journal of Medicine 383.3 (2020): 11.

8. Osseni IA. "COVID-19 pandemic in sub-Saharan Africa: preparedness, response, and hidden potentials. Tropical Medicine and Health 48.1 (2020): 1-3.

9. NCDC. "First case of corona virus disease confirmed in Nigeria" (2020).

10. Coronavirus live updates. "Lesotho becomes last African nation to report a coronavirus case". Los Angeles Times (2020).

11. Kebede Y., et al. "Knowledge, perceptions and preventive practices towards COVID-19 early in the outbreak among Jimma university medical center visitors, Southwest Ethiopia". PLoS One 15.5 (2020): e0233744.

12. Akalu Y., et al. "Knowledge, Attitude and Practice Towards COVID-19 Among Chronic Disease Patients at Addis Zemen Hospital, Northwest Ethiopia". Infection and Drug Resistance 13 (2020): 1949-1960.

13. Tessema SK and Nkengasong JN. "Understanding COVID-19 in Africa”. Nature Reviews Immunology 21 (2021): 469-470.

14. WHO. "A second COVID-19 case is confirmed in Africa" (2020).

15. CDC. "COVID-19 dashboard" (2020).

16. Africa CDC. "Africa CDC - COVID-19 daily updates". (2020).

17. "First case of corona virus disease confirmed in Nigeria". Nigeria Centre for Disease Control (2020).

18. 'Coronavirus: Nigeria 'strengthens' surveillance at five international airports". Premium Times 29 January (2020).

19. Ifijeh Martins. "FG Sets up Coronavirus Preparedness Group".
This Day Newspaper (2020).

20. "COVID-19 in Nigeria: The lies they told!". The Informant 247 News (2021).

21. https://www.worldometers.info/coronavirus/

22. Minister Zweli. "Mkhize reports first case of Covid-19 Coronavirus". South African Ministry of Health. $5^{\text {th }}$ (2020).

23. "South Africa moves to lockdown level 1 - here are the changes" (2020).

24. Evans Jenni. "Covid-19: SA enters second wave as Mkhize warns of surge in infections among teens". News 24 (2020).

25. "Ramaphosa urges diligence as he tightens Covid-19 restrictions". Business LIVE (2021).

26. “COVID-19 Weekly Epidemiology Brief”. Week 18 (2020).

27. Ferial Haffajee., et al. "Coronavirus Explainer: Maverick Insider Covid-19 Questions, Answered”. Daily Maverick (2020).

28. "Egypt announces first Coronavirus infection". Egypt Today (2020).

29. Kasraoui S. "Morocco Records First Case of Coronavirus" (2020).

30. "Ethiopia confirms first coronavirus case: Live updates". aljazeera.com (2020).

31. Reuters. "Libya confirms first coronavirus case amid fear over readiness" (2020).

32. Al Jazeera. "Libya frees more than 450 prisoners to stem spread of coronavirus" (2020).

33. Reuters. "Tunisia reports no new coronavirus cases for the first time since early March" (2020).

34. Reuters. "Congo records five new Ebola cases, shelves declaration of end to epidemic" (2020).

35. "Democratic Republic of Congo sees $1^{\text {st }}$ coronavirus death". www.aa.com.tr (2020).

36. "Deadly COVID-19 Delta variant taking hold in Africa". SubSaharan Africa (2021).

37. "Rwanda confirms first case of coronavirus - health ministry" (2020). 
38. Ashimwe Edwin. "Rwanda deploys drones to raise Covid-19 awareness in communities" (2020).

39. Paradise Seychelles is Covid-19 free. Travel Daily News International (2020).

40. Bonnelame Betymie. "Seychelles upgrades COVID-19 precautions for travellers amid global spike in cases". Seychelles News Agency (2020).

41. Burke J. "African nations impose stricter measures as coronavirus spreads". The Guardian (2020).

42. Status for udvikling af B.1.1.7 og andre mere smitsomme varianter i Danmark (in Danish). Statens Serum Institut (2021).

43. "WHO Director-General's statement on Tanzania and COVID-19". World Health Organization 20 (2021).

44. "Outbreak brief 77: Coronavirus disease 2019 (COVID-19) pandemic”. Africa CDC (2021): 10.

45. Aborode AT., et al. "Equal access of COVID-19 vaccine distribution in Africa: Challenges and way forward". Journal of Medical Virology 93.9 (2021): 5212-5215.

46. Reuters. "Nigeria to reopen vaccination for first COVID-19 shots" (2021).

47. “Government officials have dismissed COVID-19 vaccines and promoted unfounded remedies". Munyaradzi Makoni reports 397 (2021).

48. https://www.orfonline.org/expert-speak/rising-cases-of-covid-in-seychelles/

49. https://www.theafricareport.com/63232/africa-covidwhich-countries-are-responding-best-to-the-crisis /

50. Drissi Bourhanbour A and Ouchetto O. "Morocco achieves the highest COVID-19 vaccine rates in Africa in the first phase: what are reasons for its success?" Journal of Travel Medicine 28.4 (2021): taab040.

\section{Assets from publication with us}

- Prompt Acknowledgement after receiving the article

- Thorough Double blinded peer review

- Rapid Publication

- Issue of Publication Certificate

- High visibility of your Published work

Website: www.actascientific.com/

Submit Article: www.actascientific.com/submission.php Email us: editor@actascientific.com

Contact us: +919182824667 